НАУКОВИЙ ВІСНИК

H.

Cientific messegger of Livi National University
Veterinary Meedicine and Biotechnologies

now

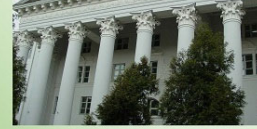

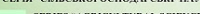

Toм 21 № 91

2019
Науковий вісник Дьвівського національного університету ветеринарної медицини та біотехнодогій імені С.3. Гжицького. Серія: Сідьськогосподарські науки

Scientific Messenger of Lviv National University of Veterinary Medicine and Biotechnologies. Series: Agricultural sciences

UDC 639.3.03:502.743

\title{
Threats to salmon and endangered fish species in Tysa river basin within trans Carpathian region (review)
}

\author{
V.P. Terpay
}

Transcarpathian scientific-research station lososivnytstva and conservation of endangered species NAAS Institute of Fisheries

\section{Article info}

Received 06.09.2019

Received in revised form 07.10 .2019

Accepted 08.10.2019

Transcarpathian scientific-research station lososivnytstva and conservation of endangered species NAAS Institute of Fisheries, Uzhhorodska Str., 165, Mukacheve 89600, Ukraine.

Tel.: +38-095-260-75-00

E-mail:trsif@ukr.net
Terpay, V.P. (2019). Threats to salmon and endangered fish species in Tysa river basin within trans Carpathian region (review). Scientific Messenger of Lviv National University of Veterinary Medicine and Biotechnologies. Series: Agricultural sciences, 21(91), 37-48. doi: 10.32718/nvlveta9107

Establish ways of creating, thoroughly investigate the threats and their level of salmon and endangered fish species Tysa River Basin within Zakarpattia region. Rate of change, diversity, distribution, the proportion of individual species, to the distribution of geographic elements on the principle of zoning and depending on environmental conditions. The study of threats to salmon and endangered species of fish in the river Tysa carried tributaries and in areas watercourse Transcarpathian region using generalized results of hydrological, ichthyological and toxicological studies. Number of species status of populations, evaluated on the basis of documents, monitoring of rivers, ichthyological data during in 2008-2014 years of control catching specialists Department of the use, reproduction of water bio-resources and regulation of fisheries in the Transcarpathian region, the State Administration of Environmental Protection in Zakarpattya region, published and unpublished sources, a survey of local fishermen. Collection and processing of materials performed by conventional methods. Comparison of species composition of fish fauna of the Tysa River Basin within Zakarpattia region on the results of previous studies and the current state of evidence that it has changed significantly. Analysis of data for 1926-2015 years revealed the presence of 77 species, which is 41.5 percent more than the same period in 1926. However, should point to the increase in the number and activities of various threats to salmon and other valuable fish species in our region. Established prolonged human pressure, pollution reduced the number of new European grayling and Trout v 13.4 times. There were 16 species, including salmon, listed in the Red Book of Ukraine. Ceased to meet sturgeon passage. Study threats operation populations of salmon and endangered species gives reason to believe that the level of destruction of natural resources, environmental pollution, depletion of the gene pool is too narrow to study hydro. For the first time a comprehensive assessment of threats to salmon, valuable and endangered local fish Transcarpathia in terms of various specific human impact of their pressure from environmental factors in the past and now. A study of the action of environmental factors and implementation of scientifically based measures to restore fish in close to natural. The results can be used in developing preservation methods, quantitative growth of populations of salmon and endangered species not only in Zakarpattya but also in the Carpathian region, water protection planning activities.

Key words: Trout, grayling European, Danube salmon, climate anomalies, ecological balance, anthropogenic load agrobiocenoses, fish fauna.

\section{Загрози лососевим і зникаючим видам риб басейну річки Тиса в межах Закарпатської області (огляд)}

\author{
В.П. Терпай
}

Закарпатська науково-дослідна станиія лососівництва та збереження зникаючих видів риб Інституту рибного господарства НААН, м. Мукачеве, Україна 
Мета роботи встановити шляхи формування, всебічно дослідити загрози і їх рівень лососевим та зникаючим видам риб басейну річки Тиса в межах Закарпатської області. Оцінити зміни розвитку, різноманітність, поширення, питому вагу окремих видів, провести розподіл на географічні елементи за принципом зональності та залежно від умов зовнішнього середовища. Вивчення загроз лососевим і зникаючим видам риб проводили в річці Тиса та притоках на ділянках водотоку Закарпатської області використовуючи узагальнені результати гідрологічних, іхтіологічних та токсикологічних досліджень. Кількість видів, стан популяцій, оцінювали на основі документів, моніторингу річок, іхтіологічних даних під час проведення у $2008-2014$ роках контрольних ловів фахівцями Управління охорони, використання, відтворення водних біоресурсів та регулювання рибальства в Закарпатській області, Державного управління охорони навколишнього природного середовиша в Закарпатській області, надрукованих і неопублікованих джерел, опитування місиевих рибалок. Збір та опрацювання матеріалів здійснювали за загальноприйнятими методиками. Порівняння видового складу іхтіофауни басейну річки Тиса в межах Закарпатської області за результатами попередніх досліджень і сьогоднішнього стану свідчать про те, щчо він значно змінився. Аналіз даних за 1926-2018 роки виявив наявність 77 видів, щзо на 41,5 відсотка більше, ніж аналогічний показник в 1926 рочі. Водночас варто вказати на зростання кількості та дї різноманітних загроз для лососевих і інших цінних видів риб у нашому краї. Встановлено затяжне антропогенне навантаження, нові забруднення які знизили чисельність харіуса європейського і струмкової форелі в 13,4 разу. Зафіксовано 16 видів, включаючи лососеві, занесених до Червоної книги Украӥни. Перестали траплятися прохідні осетрові. Вивчення загроз, функиіонування популяцій лососевих і зникаючих видів риб дає підставу стверджувати, щчо рівень знищення природних ресурсів, забруднення довкілля, збіднення генофонду є дуже гострим для досліджуваної гідроекосистеми. Вперше проведено комплексну оцінку загроз лососевим, цінним і зникаючим місцевим рибам Закарпаття в умовах специфічного антропогенного впливу різноманітних за своїм пресингом екологічних чинників у минулому і тепер. Запропоновано вивчення дії екологічних факторів і впровадження науково обгрунтованих заходів щъодо відновлення риб в умовах наближених до природних. Результати роботи можуть використовуватись при розробиі способів збереження, кількісного росту популяцій лососевих та зникаючих видів не тільки у Закарпатській області, а й Карпатському регіоні, плануванні водоохоронної діяльності.

Ключові слова: струмкова форель, харіус європейський, дунайський лосось, кліматичні аномалї, екологічна рівновага, антропогенні навантаження, агробіоченози, іхтіофауна.

\section{Вступ}

Серед величезного різноманіття організмів, що населяють біоти земної кулі, істотне місце посідають риби, які, за даними різних авторів Т. Франк, 1982, Б. Куркін та ін., 1985, І. Шерма та ін., 2009 налічують на даний час від 27 тис. до 28,5 тис. видів. Однак кліматичні аномалії, людська діяльність негативно впливають на чисельність та видовий склад цих холоднокровних тварин. Вчені прогнозують, що лише так зване глобальне потепління може спричинити зникнення щонайменше 20-30\% видів тварин або 40-70\% при найнесприятливішому розвитку подій. Геоекологічна ситуація за багатьма показниками все погіршується. Відповідно до підрахунків Всесвітньої організації охорони здоров'я (ВОО3), в період з 1985 по 1995 рік у навколишнє середовище потрапило стільки відходів, скільки було вироблено за попередні 70 років. За 1995-2000 роки така ж кількість. Техногенні утворення тільки окисів сірки у 1988 році оцінювались в 175 млрд т. Саме тому на початку третього тисячоліття проблема взаємодії людського суспільства та біосфери стоїть на другому місці після політичної. Увага міжнародної спільноти привернута до іiі розв'язання, збереження генетичного представництва органічного світу. Зокрема, конференцією ООН „Ріо + 20 Майбутнє, якого ми прагнемо" 22 червня 2012 року ухвалено підсумковий документ, взято курс на збалансований розвиток і забезпечення побудови економічного, соціального та екологічного майбутнього для нинішнього й наступних поколінь. На необхідність вирішення екологічної проблеми вказали учасники Римського клубу А. Печчені, Дж. Форрестер, Д. Медоуз, М. Месарович, Б. Гаврилишин та ін. Цю ідею розвинули і внесли свій вклад у дослідження наші вчені С. Стойко, М. Голубець, Ю. Туряниця, Г. Рудько, О. Адаменко, М. Демчишина та ін. (Dovbenko, 2007).
Адміністративне регулювання якості навколишнього середовища започаткувала Японія ще у 1964 році, прийнявши закон про боротьбу із забрудненням навколишнього середовища. США в сфері охорони повітряного простору (1970), Данія про кислотні дощі (1984), Україна про охорону навколишнього природного середовища (1991). Хоча державою прийнято закон, техногенне навантаження на природне середовище перевищує аналогічний показник розвинених країн у 4-5 і більше разів. При цьому, незважаючи на значний спад виробництва, зниження обсягів забруднення, що утворюється на промислових підприємствах і потрапляє в повітря, водні об'єкти та грунти, не викликало адекватного зменшення. Створюється загроза завдання непоправної шкоди біологічному й ландшафтному різноманіттю - лісовим, гірським екосистемам, водоймам, лукам, землям тощо. Лише за останне десятиріччя від промислових викидів загинуло 2,5 тис. га лісових насаджень С. Стойка, 2011. Найвища розорюваність сільськогосподарських угідь - 80\% спричинила переущільнення грунтів. Стан води i повноводдя річок Південний Буг, Західний Буг, Дністер, Прут, Тиса та інших тривожний, оскільки 20 тис. їх приток та малих річок уже висохли. Варто зазначити, що вода - єдиний розчинник на планеті, завдяки ій відбувається переміщення речовин із навколишньої неживої природи до живих організмів. Разом зі зникненням водойм зникли всі живі в них організми. Крім вичерпання біологічного різноманіття, втрачено своєрідні індикатори екологічного стану не тільки водних екосистем, що висохли а й усієї площі водозбору. Щоб досягти збереження величезної кількості видів, вразливої живої природи басейну ріки Дунай і Карпатських гір, Європейський Парламент та Рада 23 жовтня 2000 року прийняли нову Водну Рамкову Директиву 2000/60/СС. Україною і 6-ма країнами Центральної та Східної Свропи у квітні 2001 року створено Карпатський Екорегіон. Звідси випливає науковий і практичний висновок, що басейн річки 
Тиса відіграє не тільки для Закарпаття, а й країн Карпатського регіону важливу соціальну, економічну, ресурсну, кліматоутворюючу, екологічну роль та збереження видового багатства фауни і флори. Стійкий розвиток краю тісно пов'язаний з оптимізацією функціонування єдиної еколого-економічної системи. Проте навіть зміна форм власності практично не поліпшила екологічний характер виробництва, він став ще більш споживацьким. Продовжується інтенсивне виснаження природного потенціалу. Власники підприємств намагаються отримувати максимальні прибутки, часто нехтуючи екологічною компонентою. Недопустимо вирішувати соціальні проблеми за рахунок погіршення екологічної ситуації, оскільки остання може лягти в процеси функціонування єдиної еколого - економічної системи. Перехід іiі за критичну межу, де починаються вже незворотні процеси, означає, що жодні заходи не допоможуть природі набути того стану, який був до його порушення. 3 огляду на зазначене, першочергова увага повинна приділятися водоймам, як найбільш важливим і мобільним. Адже у межах Закарпаття надзвичайно багато річок, струмків та потоків з основним біотопом галька, валуни, рідше глиби, природні умови яких сприятливі для мешкання лососевих i зникаючих видів риб. Тому постійні комплексні дослідження річкової системи є дієвою формою контролю за їх станом, одним із найефективніших способів визначення загроз у кожному конкретному водотоку області.

Іхтіофауна зазнала значної трансформації в той час, коли почали масові вирубки лісів, активне заселення гірської зони, а низинні ріки у багатьох місцях були спрямлені, відрегульовані та взяті під контроль (Ю. Мовчан, 1986.) Ї̈̈ кількість, видовий склад та структура значно відрізняється від наявної до урбанізації, розвитку промисловості. Рибна продуктивність річок коливається, то збільшуючись, то зменшуючись в декілька разів. Окремі види - на межі зникнення. Чисельність лососевих і місцевих цінних видів риб невпинно зменшується. Наприклад, продуктивність струмкової форелі та харіуса європейського складає лише 1,4 кг/км (Mruk et al., 2011). Тож вони потребують впровадження заходів щодо підтримки. Зарегулювання Дунаю водосховищем призвело до того, що осетрові не водяться і не запливають в Тису. Натомість розселилися акліматизовані види.

Менші ріки і донині залишилися переважно в своєму природному стані, особливо гірські, тож досить добре репрезентують аборигенні та зникаючі види риб. Загалом таких виявлено 51 вид (Ю. Мовчан 1991), що дозволяє зберегти різні гено-, фено-, і екотипи. Майже не порушені антропогенним впливом популяції є тією науковою лабораторією, де можна вивчати, використовуючи досягнення генетики та молекулярної біології, закономірності та механізми функціонування генетичного апарату, рух генетичної інформації у поколіннях, походження видів, географічне розповсюдження та генетичну різноманітність риб. I тому, незважаючи на складність здійснення, треба проводити роботи з оцінки загроз, охорони та відтворення, забезпечити інвентаризацію місць поширення, моніторинг за станом, динамікою цих рідкіс- них таксонів. Необхідно визначити рівень загроз за їх впливом, особливо на лососеві, тому що за чутливістю до дії зовнішніх чинників вони належать до чутливих. Індикатори, за якими буде оцінюватися вплив загрозливих факторів, та методики їх оцінки. Послідовне, глибоке вивчення реакції особини протягом всього життя та діапазон дії окремих екологічних факторів на конкретний етап і відрізок онтогенезу. Дану роботу може виконати Закарпатська науководослідна станція лососівництва та відтворення зникаючих видів риб (ЗНДСЛ та ВЗВР) Інституту рибного господарства НААН разом із зацікавленими організаціями. Але на перешкоді стоять фінансові труднощі. Незважаючи на це, ЗНДСЛ та ВЗВР знаходить можливості та проводить дослідження не тільки в природних водоймах, лабораторних умовах, а й створює полігон з метою глибокого вивчення реакції риб на вплив різних природних і антропогенних факторів в максимально наближеному до природного середовищі. Для цього на річці Іршавка, в межах дослідного рибного господарства, будується дільниця, що дасть змогу забезпечити сучасніші підходи в проведенні наукових досліджень, надати їм практичного напряму. Також детально вивчати ймовірні негативні наслідки загроз, процеси самовідтворення, ріст і розвиток лососевих у майже природних умовах, вирощувати адаптованих особин з метою подальшого випуску в річки, підтримувати хоча б на мінімальному рівні чисельність популяцій лососевих і відтворювати зникаючі види риб у регіоні Карпат.

Довготривале, інтенсивне використання лісів і річок та антропогенний тиск спричинили збіднення гідробіонтів, які визначають значною мірою умови існування риб, особливо лососевих, що теж належать до вказаної групи, деградацію, висихання окремих малих водотоків. 3 огляду на це виникла потреба в докладнішому проведенні комплексного дослідження, вивчити загрози та причини їх виникнення для риб у всьому ланцюгу екзогенних факторів зовнішнього середовища. В умовах зростаючого впливу несприятливих факторів на гідроекосистеми вивчення загроз, які спричиняють появу широкого спектру патологічних станів у всіх живих організмах, оптимізація природного та штучного відтворення риб досить значуща й актуальна.

Рядом авторів В. Владиков, 1926; І. Колюшев, 1949; К. Владиков, 1965; В. Мовчан, 1986; Ф. Куртяк, 2010 дана фрагментарна оцінка загроз окремих водотоків і водойм іхтіофауні в Закарпатській області. Метою проведених нами досліджень було поглиблене вивчення, аналіз та визначення причин виникнення глобальних і локальних загроз, викликаних дією природних та антропогенних факторів, а також їхнього можливого впливу на лососеві та зникаючі види риб. Здійснити науковий аналіз стану іхтіофауни, отримати нові дані про загрози цінним рибам річки Тиси 3 притоками в межах України.

\section{Матеріал і методи досліджень}

Матеріалом для досліджень служила іхтіофауна i басейн верхньої р. Тиси. В роботі використано такі 
методи: збір інформації, обробка, узагальнення, інтерпретація отриманих документів, 3 допомогою яких досліджувалися та вивчалися виникнення загроз іхтіофауні та конкретно цінним видам риб басейну річки Тиса в межах Закарпатської області. Проводився комплексний аналіз екосистеми, встановлювались залежності між факторами впливу загроз, вивчався колишній і нинішній стан іхтіопопуляцій, відтворення риб в природних умовах, їх збереження, саморегулювання й самовідновлення. При написанні роботи були використані літературні відомості вищевказаних авторів, матеріали контрольних ловів фахівцями Управління охорони, використання, відтворення водних біоресурсів та регулювання рибальства в Закарпатській області за 2008-2018 роки та власні дослідження. Використано знаряддя лову сітки ставні 3 a $=21-90$ мм (Proniuk, 2011), човен гумовий ЛАС-21, волоки, сачки. Повидовий огляд подається за визначником довідником "Риби України” Ю.В. Мовчана, 2011. Контрольні лови проводились в межах Рахівського району в с. Кваси, с. Богдан, с. Ділове, с. Великий Бичків, с. Біла Церква, - гірського району; Хустського району - в с. Буштино, с. Вишково, с. Стеблівка, с. Сокирниця, м. Хуст, с. Крива передгірного району, басейну річки Тиса на ділянках низинного Ужгородського району.

\section{Результати та їх обговорення}

У процесі досліджень вивчено особливості екологічного, термічного, гідрохімічного, гідробіологічного режимів водного фонду Закарпаття, який формує система р. Тиси. До нього належать 9436 великих і малих річок сумарною довжиною 19793 км, площею водного дзеркала 15 тис. га. 3 них 153 мають довжину понад 10 км, загальну - 3543 км, 2030 менше ніж 10 км, а Тиса, Боржава, Латориця й Уж - понад 100 км кожна (в межах області) та 137 озер, більшість 3 яких висихає, постійних - 32. Пересічна густота гідрографічних об'єктів складає 1,7 км/км², що є найвищим показником в Україні. На 1 км² припадає 388 тис. м ${ }^{3}$ води (Рор, 2002). Така густа мережа річок, потоків і озер підтримує широке видове різноманіття. В сучасній фауні налічується 30438 видів, безхребетних 20 типів організмів, 3 яких більшість - найпростіші. Близько 400 видів хребетних тварин, ссавців - 80, птахів -287 , плазунів - 10 , земноводних -16 , риб -77 , молюсків - 100, що сприяє збереженню природної спадщини. Локалітети лососевих, осетрових, коропових, окуневих, вугрових та інших видів риб і круглоротих - Тиса з притоками, Тересва, Теребля, Ріка, Боржава, Латориця, Уж та ін. Свій початок всі вони беруть у Карпатах на висоті 1300-1700 м над рівнем моря (м н. p. м.). Створюють водозбірну територію площею 35396,8 км² 3 яскраво вираженим гірським, передгірним залісненими і рівнинним, покритим рослинністю ландшафтом, виділенням орфографічних одиниць: низина - 105-130 м н. р. м; передгір'я - від 130 до
350-400 м; гори - від 350-400 до 2050 м н. р. м. характерною висотною поясністю клімату. Русла у витоках мають ухил понад 100 м/км, швидку та бурхливу течію (до 3-5 м/с), незначну глибину (0,5-1,5 м), ширину - 10-40 м. Наявні пороги, водоспади, круті берегові схили, кам'янисте, гальково-піщане дно. Зазнали менших втрат, зберегли в багатьох місцях свій умовно первісний стан, екологічний феномен. Водообмін відбувається за декілька днів. В передгір'ї і долинах розширюються, течії більш спокійні, багаті старицями. Двадцять відсотків водойм відносяться до холодноводних оліготрофних, олігосапробних з температурою протягом року 8-16 градусів, бідною кормовою базою, збагачені киснем - 11-12 мг/л.

Мінералізація та загальна твердість води з роками помітно зростає. Зараз мінералізація становить 230 390 мг/л. Вода гідрокарбонатного класу кальцієвої групи. Вниз по течії стає більш твердою - від 11,2 градусів до 17,8, крім річки Уж, де вона м'яка, слабомінералізована. Виявлена така ж тенденція до погіршення якості та відповідає класам і категоріям якості за ступенем чистоти від дуже чистої до слабко забрудненої.

Варто зазначити, що при вивченні загроз іхтіофауні такий підхід дає можливість конкретно розібратися у складній мозаїці екологічних факторів, що впливають на біосистеми, в тому числі й на іхтіофауну. Тому що в цих природно-географічних, гідробіологічних, гідрохімічних і термічних умовах проходив процес іiі формування, визначається розвиток. Вона дуже своєрідна і надчутлива та вразлива до будь-якої антропогенної дії, особливо цінні стенобіонтні реофільні види, основу яких складають лососеві родів Salmo, Hucho, Thymalus. У зоогеографічному плані входить до складу специфічної Тисянської підділянки Дунайської ділянки Дунайсько-Дністровського району Чорноморсько-Азовської округи Понто-КаспійськоАральської провінції. За таксономічним складом, кількісними показниками та біотопічним різноманіттям ми виділяємо іхтіоценози: гірський, передгірний i низинний.

3 метою отримання максимально достовірних даних значний інтерес становить дослідження акваторії Тиси, де чітко прослідковуються характерні для закарпатських річок ділянки, формуючі основні абіотичні та біотичні компоненти екосистеми, якість води, різноманіття кормової бази, унікальні аборигенні іхтіоценози з особливим видовим складом і домінуючими групами (табл. 1).

На прикладі річки Тиса показано систематичну різноманітність, поширення i питому вагу окремих видів іхтіофауни всього регіону. Розподіл іiі на географічні елементи проведено за принципом зональності. Помітна вертикальна диференціація, зміни досліджуваних представників. Наші порівняння пов'язані 3 показниками гірської зони, прийнятими за базові. 
Таблиця 1

Видовий склад риб та круглоротих контрольних уловів 2008-2014 років на річці Тиса

\begin{tabular}{|c|c|c|c|c|c|c|c|c|c|c|c|c|c|c|c|}
\hline \multirow[b]{2}{*}{$\begin{array}{c}\text { Екологі- } \\
\text { чні } \\
\text { зони }\end{array}$} & \multirow[b]{2}{*}{ 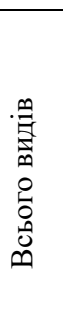 } & \multicolumn{14}{|c|}{ Представники іхтіофауни, відсотки } \\
\hline & & 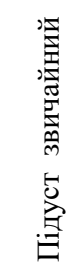 & 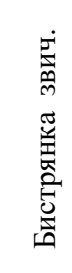 & 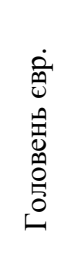 & 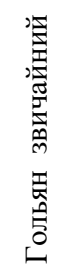 & 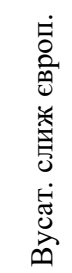 & 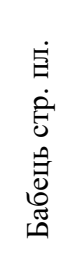 & 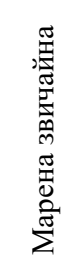 & 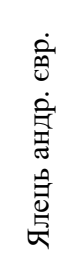 & 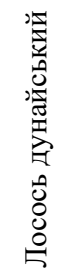 & 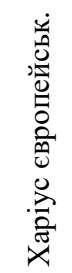 & 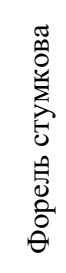 & 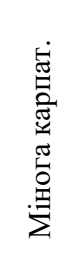 & 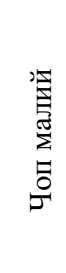 & 声 \\
\hline Гірська & 13 & 1,5 & 27,6 & 5,4 & 7,9 & 3,9 & 5,9 & 14,3 & 7,9 & 1,9 & 9,9 & 8,9 & 3,9 & 1,0 & - \\
\hline $\begin{array}{l}\text { Перед- } \\
\text { гірська }\end{array}$ & 31 & 36,7 & 13,6 & 9,3 & 8,1 & 7,3 & 3,1 & 4,2 & - & 1,0 & - & - & - & 0,3 & 16,4 \\
\hline Низинна & 37 & 40,0 & 13,7 & 7,3 & 8,1 & 11,3 & 3,0 & 2,1 & 0,3 & 0,8 & - & - & - & 0,3 & 13,1 \\
\hline
\end{tabular}

Як видно з одержаних даних, розподіл риб та круглоротих детермінується 3 екологічними факторами, біологічними потенціями видів. Діляться на види із обмеженим поширенням і 9 видів широкого екологічного діапазону, спільні для всіх ділянок. За біотопічною приуроченістю належать до реофільних, епібіонтних, лімнофільних, еврібіонтних.

Згідно із зональною схемою, традиційно верхів'я Тиси затінені деревами, що не дає перегріватися воді влітку, де немає конкурентів щодо їжі та плодовитості, як і раніше, заселені лососевими (Salmonidae), але їхня частка складає уже тільки 20,7\%. За оцінкою О. Герман, 1887 кількість риби зменшилась спочатку у 100 , а пізніше - $з$ розвитком промисловості і збільшення заводських стоків, - майже у 1000 разів. Гірський фауністичний комплекс, дані Закарпаття рибохорони, до висоти 1000 м н. р. м. освоїла форель струмкова (Salmo trutta trutta morpha fario Linnaeus, 1758). Типовий представник Синевирського озера (висота н. p. м. - 989 м) - форель озерна (Salmo trutta trutta morpha lakustris Linnaeus, 1758). Харіус європейський (Thymallus thymallus Linnaeus, 1758) мешкає до 800 м н. p. м.. Нижче за течією до 600 м н. р. м. займають поодинокі екземпляри ендеміка, релікта, єдиного представника в Україні роду Таймень - Hucho Gunther, 1866 лосось дунайський, головатиця (Hucho hucho Linnaeus, 1758). Наймасовіша на вказаному відтинку серед спійманих риб та круглоротих зареєстрованих в контрольних ловах бистрянка звичайна. Далі йде марена звичайна. За ними - форель струмкова, харіус європейський. Досить численні ялецьандруга європейська, гольян звичайний. Іхтіофауна гірської зони всього охоплює 13 видів, що складає 16,9 відсотка від загальної кількості видів регіону дослідження, 3 яких 5 перебувають під охороною держави.

В середній, і особливо нижній, течіях утворюється значна кількість озер весняними паводками, де проходить розмноження та ріст молоді тепловодних, пізновідкладаючих ікру риб. За рахунок цього рибне населення перерахованих ділянок більше кількісно, різновидніше за якісним складом, ніж у верхній течії, налічує відповідно 31 і 37 видів. Тут частіше розповсюджені підуст звичайний, головень європейський, гольян звичайний, вусатий слиж європейський, бист- рянка звичайна, рідко - стерлядь прісноводна, лосось дунайський, рибець звичайний, чехоня звичайна, чоп малий, чоп великий, щука звичайна, гірчак європейський, сом європейський, йорж смугастий, карась звичайний, йорж звичайний, пічкур дунайський та ін.

За регіональною ознакою їх поширення та кількістю особин ми розподілили за такими групами: види, звичайні у іхтіофауні Закарпаття і України загалом; види, які є звичайними у іхтіофауні регіону, а за його межами не зустрічаються; рідкісні, вразливі, зникаючі види, поширені в Карпатах; рідкісні, вразливі, зникаючі види, поширені виключно в Закарпатті; зниклі види; вселені види.

Загалом в іхтіофауністичному комплексі Закарпаття порівняно велику частину складають види другої групи - мінога карпатська, пічкур дунайський, чоп малий, йорж смугастий, лосось дунайський, головатиця та ін. Стерлядь прісноводна (Acipenser ruthenus Linnaeus, 1758) - єдиний представник риб родини осетрових, що постійно живе в прісній воді Тиси. Однак під загрозою зникнення опинилася значна кількість видів другої, третьої і четвертої груп - мінога карпатська, стерлядь прісноводна, ялець-андруга європейська, ялець звичайний, пічкур дунайський, білоперий пічкур дністровський, минь річковий, умбра звичайна, карась звичайний, марена дунайськодністровська, марена звичайна, лосось дунайський, головатиця, харіус європейський, чоп малий, чоп великий, йорж смугастий, і тому занесені до третього видання Червоної книги України за 2009 рік. Крім перерахованих, до Червоної книги Українських Карпат у 2011 році ввійшли - річковий вугор європейський, йорж носар, йорж Балона, берш (малий судак), рибець звичайний (Akimov, 2009; Meteleshko \& Potish, 2011). 3 матеріалів природноохоронних списків за 1994 рік прослідковується чітка тенденція до збільшення кількості видів, що перебувають на межі зникнення 10; 16; 21 відповідно, або 12,9; 20,8 і 25,9 відсотків від наявних. Таким чином, за 17 років цей негативний процес зріс у 2,1 разу. Скласти уявлення про потенційну небезпеку дозволяють також отримані дані розподілу круглоротих і риб з водних теренів регіону розміщених у третьому виданні Червоної книги України за 2009 рік, за категоріями: 47,4\% вразливі; 31,6\% - зникаючі; 15,7\% - рідкісні; 5,3\% - 
неоцінені, тимчасом як у 1994 році відповідно - 50\%; $10 \% ; 40 \% ; 0 \%$. У кінцевому підсумку все це можна пояснити прогресуючим втручанням людини в органічне життя вод, яке відбувається так швидко, що виникає невідповідність між біологічною природою, фізіологічними можливостями організму і зовнішнім середовищем.
Порівняльний склад рибного населення річки Тиси 3 притоками за результатами попередніх спостережень, 19 століття і сьогодення свідчить про те, що воно суттєво змінилося. Окремі автори у першій половині 20 століття писали про великі запаси форелі.

Таблиця 2

Ділянки розповсюдження струмкової форелі в басейні річки Тиса (за Анучан В.А., 1956)

\begin{tabular}{lccc}
\hline \multirow{2}{*}{ Назва річки } & \multicolumn{2}{c}{ Форелева ділянка } & Нижня границя, \\
\cline { 2 - 3 } Тиса & Висота розміщення, м н. р. м. & протяжність, км & Ділове \\
Латориця & $443-920$ & 70 & Неліпино \\
Тересва & $300-780$ & 80 & Нересниця \\
Уж & $250-980$ & 65 & Перечин \\
Теребля & $250-700$ & 70 & Теребля \\
Ріка & $250-790$ & 65 & Липча \\
Боржава & $250-700$ & 60 & Іршава \\
\hline
\end{tabular}

Колюшев I.I. у 1949 році зазначив: форель струмкова, харіус європейський, лосось дунайський найважливіші з промислових риб (Koliushev, 1949). Перше місце серед виловлених риб займали лососеві - підтверджено дослідженнями Діброва,1957 та інших учених. Загальна довжина оселищ струмкової форелі нараховувала 1000 км. Продуктивність іï у річках Карпатського регіону складала по 60-100 кг/км річки. Проте упродовж другої половини 20 століття запаси виду катастрофічно зменшились (біомаса у 42, чисельність у 13,4 разу) через різні стрес-фактори: дефіцит кисню, каламутність води та низку чинників антропогенного характеру i тепер становить 1,4 кг/км (15 екз/км). Граничний вік не перевищує 3 роки проти 8-12 у 1940 році (Mruk et al., 2011; 2012).

Форелеві ділянки піднялися (табл. 2), з 250 - 443 м н. р. м. до 500-550 м н. р. м., скоротивши протяжність. Варто додати, що основним іiі конкурентом за середовище існування $\epsilon$ харіус європейський, який займає порівняно чималі ділянки 14 відносно великих i великих річок. Найнижча межа його мешкання в Тисі 300 м н. р. м., Ужа, Латориці, Боржави 169-200 м н. р. м. Різниця точок складає 631 м. Зона ділянок розповсюдження - найкоротша, від 200 до 300 м н. р. м., у Шипоті, найдовша - від 280 до 800 м н. р. м., у Кісві й Тересві. Нині у річках знизилась щільність, змінились види домінанти, погіршились популяційні, індивідуальні показники та видовий склад іхтіофауни. Переважають риби з весняно-літнім періодом нересту: коропові - 53,5\%, окуневі - 16,3, інші - 25,6, лососеві та рогаткові - лише 4,6\%. Довгоциклічні та більш цінні риби (струмкова форель, харіус європейський, лосось дунайський, головатиця) заміщуються короткоциклічними і менш корисними (окунь, лящ, плітка, карась). Водночас останні відомості вказують на розширення видів. Опрацьовані матеріали на основі результатів наших досліджень наведено в таблиці 3 .

Таблиця 3

Чисельність видів риб і круглоротих басейну річки Тиса в межах Закарпатськоі області

\begin{tabular}{lccccc}
\hline & \multicolumn{4}{c}{ Автор, рік } \\
\cline { 2 - 6 } Всього видів & Владиков В., & Колюшев I., & Власова К., & Мовчан В., & Куртяк Ф., \\
& 1926 & 1949 & 1965 & 5010 & 2010 \\
\hline Кількість & 45 & 53 & 50 & 60 & 77 \\
\hline
\end{tabular}

Аналізуючи наведені дані з 1926 по 2010 роки, бачимо що видовий склад збагатився на 32 одиниці та загалом нараховує 77 таксонів. Необхідно наголосити: збільшення відбулося за рахунок інтродукованих, тих що самовільно вселилися, та нових видів риб, які раніше не були вивчені, але входили до складу аборигенної іхтіофауни. Для такої, порівняно невеликої за площею території, названа кількість видів свідчить про іiі високу фауністичну насиченість. Серед них багато цінних, рідкісних і ендеміків. Не виключено, що список риб може доповнитись новими видами або зникненням деяких.
Керувалися у своїх діях при вивченні їм загроз законом В. Шельфорд, 1913: “Природним обмежуючим чинником існування організму може бути як мінімальний, так і максимальний екологічний вплив, діапазон між якими визначає ступінь витривалості (толерантності) організму до цього чинника". Вказаний закон Ю. Одум (1975) доповнив роз'ясненнями стосовно неоднорідності впливу екологічних факторів та реакції на них живих організмів (Sherman et al., 2009). У кожного виду - свої межі. Вони визначають сприятливі умови для життя одних видів риб і непридатні для інших. 
Наукові спостереження за водними живими ресурсами, показниками якості води у водоймах області дають підставу константувати тенденції до погіршення. А. Мрук, I. Великопольський, В. Устич (Mruk et al., 2012) фіксують збіднення рибних запасів, забруднення довкілля. 3 огляду на це за станом навколишнього середовища басейну річки Тиса здійснюється постійний державний контроль органолептичним, аналітичним, соціологічним, експертним, хімічним аналізом, приладометричним, біотестуванням та іншими методами і їхнім поєднанням. Для оцінки фізико-хімічних показників складу поверхневих та зворотних вод лабораторією моніторингу вод та грунтів Басейнового управління водних ресурсів річки Тиси, науковими установами визначається температура, запах, кількість завислих речовин, прозорість, колір, електропровідність, перманганатну окислюваність, вміст розчинного кисню, біологічну потребу кисню, водневий показник (pH), питому активність радіоцезію-137, важких металів, щільний залишок, кількість солей, сульфатів, хлоридів, фенолів, нафтопродуктів, жорсткість тощо.

У процесі проведених досліджень виявлено, що на стан лососевих та зникаючих видів риб верхньої Тиси впливають різноманітні фактори, серед яких є й такі, що загрожують їх благополуччю. Тому насамперед проведено оцінку загроз і причини, що викликають загрози. Загалом скорочення чисельності риб має природне (не пов'язане з впливом людини) і антропогенне (пов'язане з впливом людини) походження. Перше - природні сукцесії екосистем, що призводять до заростання, евтрофікації і зникнення водойм. Коливання погодних умов, морози, засухи, паводки. Під впливом епідемій, викликаних вірусами і бактеріями, паразитами. Конкурентне витіснення близькими та іншими видами. Друге - пряме розрушення біотопів: осушення озер, боліт і потоків; вирубування лісів і знищення рослинності; розчистка, спрямлення водойм і будівництво гідроспоруд; розораність земель; забір води для потреб населення, гідроелектростанцій, поливу сільськогосподарських культур; лісозаготівля важкою технікою; техногенне забруднення довкілля та побутовими відходами; надмірний вилов, браконьєрство і т. п. Обидві групи загроз можуть взаємодіяти.

Моніторингом кліматичних умов встановлено, що і в нашому краї спостерігаються аномалії, пов'язані з глобальними змінами клімату на планеті. Так, згідно $з$ інформацією українського гідрометцентру, перше півріччя 2015 року найтепліше за останні 134 роки. Вчені прогнозують у 2010-2060 роках температура повітря теплого півріччя по Україні буде підвищуватись, а кількість опадів і показники вологозабезпеченості знижуватись. Глобальне потепління може викликати інтенсивніше зникнення водойм, серйозні відхилення в процесах формування статевих продуктів риб і виявитись одним із головних лімітуючих факторів для розвитку, спричинити найбільшу загрозу та згубну дію на біологічні ресурси.

Вкрай негативне та дуже поширене явище в Закарпатті - каламутність річок. Середньорічна каламутність води - від 200 до 700 г/м³ , максимальна досягає 2000 г/м³. В холодні зими на гірських річках відбува- ється намерзання по дну, нарощуються льодові пороги, що несприятливо впливає на розмноження струмкової форелі. Знищують риб льодові затори, суцільне льодовкриття.

Біологічна загроза належить інвазії чужорідних видів риб, таких як сонячний окунь, амурський чебачок, американський сомик, ротан головешка й ін. витісняючи, займаючи життєвий простір можуть нести загрози захворювань.

На кількість та якісний склад іхтіофауни впливає кормова база. За двадцять років у верхів'ях Тиси 3126 видів водних безхребетних залишилося 32, з 109 видів безхребетних ценозів макрозообентосу - 69: личинок хірономід - 24 види та форми, олігохет - 14, нимф одноденок -9 , личинок волохокрильців -7 , веснянок - 3, амфіпод - 2, інших організмів - по 1 виду. Зоопланктон на гірських ділянках річок зимою складає $1,8 \mathrm{мг} / \mathrm{M}^{3}$, передгірних ділянках $-8,5 \mathrm{мг} / \mathrm{M}^{3}$, у весняні місяці відповідно - 22,1; 34,0, літні - 187,6; 100,9, в осінні - 86,3; 68,7 мг/м³ (М. Овчаренко, 1991).

Додає проблем і досить складна епізоотична ситуація. Ключові фактори зараження риб: наявність певних збудників хвороби; рівень опірності організму риб до ураження хвороботворними організмами; умови навколишнього середовища, що сприяють проникненню у водойми і подальшому інтенсивному розвитку збудників захворювань. Збудники інфекційних захворювань - бактерії, віруси, гриби: інвазійних черви, нижчі ракоподібні, найпростіші (Hrytsyniak, 2008). Лише у верхній Тисі виявлено 20 видів паразитів риб. Епізоотії завдають шкоди не тільки тим річкам, де вони виникли, а й іншим, благополучним щодо прямої загибелі риби і зниження темпу росту. Для лососевих загрозою є вірус інфекційного панкреатичного некрозу (Н. Матвієнко та ін., 2013), для стерляді прісноводної 24 види паразитів (О. Давидов та ін., 2012).

Згідно 3 деякими оцінками, виживання майже половини видового різноманіття Карпат залежить від діяльності людини. Історично склалось так, що колоніальні режими різних держав віками та по-хижацьки використовували природні ресурси регіону. Ще у далекому 1600 році кріпаки Рахова змушені були доставити домінії серед інших натуральних податків 1000 штук струмкової форелі. Одночасно розпочато масове випалювання і викорчовування гірських лісів. Пізніше - промислову розробку і сплав дерев річками, який припинено лише у 1978 році. Показники залісненості території впали з 90\% до 51\%. На рівні адміністративних районів екстремальні значення має Берегівський р-н - 14,2\%.

Величезні вирубки, які перевищували допустимі, науково обгрунтовані норми, проводилися у 50-60-ті роки минулого століття - 2,5 млн м ${ }^{3}$ за рік та 19952002 - понад 3 млн м². Впродовж останніх 70 років в Карпатах заготовлено 100 млн м ${ }^{3}$ деревини, що абсолютно неприпустимо, враховуючи надзвичайно важливу екологічну, грунтозахисну, санітарно-гігієнічну роль лісів та виконання ними водорегулюючої функції. За оцінками В. Олійник, 2008, водоакумулююча здатність стиглих букових лісів становить 140160 мм, смерекових - 70-90 мм. Лісовий намет затри- 
мує у букових лісах 23,5\% річної кількості опадів, ялинових - 27,3\% (О. Чубатий, 1984) через неконтрольоване вирубування лісу, на водні об'єкти басейну річки Тиси антропогенні навантаження перевищили межі екосистемної екологічної ємності, зменшився модуль стоку річок. Вчені С. Стойка, 1981 та ін., М. Голубець та ін., 1994 стверджують, що тривале інтенсивне використання гірських букових пралісів Карпатського регіону та Закарпатської області спричинило оголення від дерев площі 4500 га верхньої межі приполонинських лісів, спровокувало катастрофічні незворотні наслідки. На схилах спостерігається явище підземної повені, активний розвиток ерозії. Зміни покривного біоценозу в горах зумовили збільшення поверхневого стоку в чотири рази та на $10 \%$ знизився рівень загального випаровування вологи за рахунок транспірації кронами дерев. Зсувонебезпечні площі за 30 років зросли в 5 разів, до 384,7 км². Загальна довжина ділянок бокової ерозії водотоків - 158,4 погонних кілометрів. Відбуваються регулярні паводки, які супроводжуються зсувами грунту та сельовими потоками періодичністю відповідно 9-13 і 16-17 років. Формуючи вал висотою 2,5-3,0 м, швидко рухаючись, - 3-4 м/с, руйнують оселища лососевих. Уламковий матеріал 270 селенебезпечних водотоків 3 пло-

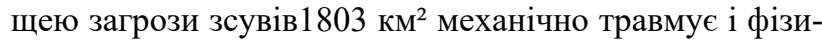
чно знищує особини. Найбільш катастрофічні паводки трапились у 1927, 1941, 1969, 1970, 1998, 2001 роках (Kosovets \& Samoilenko, 2005), останній у 2008 ріці. Щорічно 1,8 млн т змитого грунту замулюює річище та дно приток головної артерії краю. До того ж варто зауважити, що для утворення у природному середовищі гумусу потрібно 250-300 років. У перші дні після паводку вміст азоту амонійного та заліза загального у воді річки Тиси, район м. Тячева, перевищує гранично допустимі концентрації (ГДК) відповідно у 12,2-13,2 і 17,7 разу, смш. Буштино - в 11,6 і $12,5-13,5$, с. Тересва - 15,4 і $11,5-20,5$ разу. У водах річки Латориці сполуки міді - в 1-7 разів, хрому - 1-8 разів. Паводки змінюються періодами вкрай низьких меженних витрат води, під час яких стік буває в 2000 разів меншим, ніж у паводковий період (В. Олійник, 2012).

Після затоплення територій у 1869 і 1888 рр. розпочато водогосподарське будівництво i проведено значний обсяг робіт, унаслідок чого зарегульовано більшість річок водозахисними дамбами загальною довжиною 765,5 км, берегоукріплювальними спорудами - 318,8 км, каналізуванням русел - 1339 км, гідротехнічними спорудами - 1108 штук, перекрито 9-ма греблями (табл. 4). Наявний водогосподарський комплекс змінив гідрологічний режим річок. Зрештою, уповільнення течії у руслових водосховищах сприяли виникненню замулення, заростання водного плеса вищою рослинністю. Утворилися популяції, невластиві даній географічній зоні двостулкових молюсків, щосезонна альгофлора, бактеріо-та фітопланктон.

\section{Таблиця 4}

Водосховища Закарпатської області

\begin{tabular}{|c|c|c|c|c|}
\hline Населений пункт & Назва водосховища & Басейн річки & Сумарна площа дзеркала,га & Об'єм, тис. м ${ }^{3}$ \\
\hline м. Виноградів & Сальвінське & Сальва & 101,0 & 1400 \\
\hline с. Вільшани & Теребле-Рікська ГЕС & Теребля, Ріка & 155,0 & 24000 \\
\hline c. Залуж & Бабічка & Латориця & 170,0 & 5800 \\
\hline с. Пістрялово & Мочила & - & 156,0 & 3900 \\
\hline c. Форнош & Форнош & - & 285,0 & 5200 \\
\hline с. Горбок & Роман-Потік & - & 246,0 & 7400 \\
\hline с. Бобовище & Бобовищанське & Полуй & 31,0 & 1590 \\
\hline с. Андріївка & Андріївське & Латориця & 74,0 & 2590 \\
\hline с. Бороняво & Бороняво & Боронява & 65,0 & 1100 \\
\hline
\end{tabular}

Ці зміни порушили умови життя цінних і зникаючих видів риб, спричинили частини природних нерестовищ (Proniuk, 2011). Доведено, після будівництва греблі та гідроспоруд на Дунаї в Угорщині припинилося запливання на українську ділянку Тиси прохідних осетрових білуги, осетра, севрюги. Мігруючі види змушені були змінювати відстань, тривалість, часто й напрям міграцій, а рибець звичайний, пристосовуючись, утворив немігруючі популяції. Все рідше зустрічаються аборигенні види.

Раритетна компонента басейну річки Тиси являє собою значну цінність у контексті збереження локального і світового значення біорізноманіття. Екологи, екофілософи і природоохоронники різних континентів у своїх працях підкреслюють, що зберігати дику природу - означає зберігати іiі автономію і свободу. Багато видів зникають швидше, ніж вони можуть бути замінені еволюційним шляхом (Kyselov \& Kanak, 2000).

Через цілеспрямоване осушування водноболотного масиву в кількості 183,7 тис. га окремі види риб стали рідкісними або опинилися на межі зникнення. Зокрема, великий своєрідний природний об'єкт Чорна Мочар площею близько 13 тис. га. до меліорації являв собою невисихаючу, зарослу очеретом та іншими водними рослинами місцевість, що використовувалась як мисливські угіддя. Будівництво на потоках чотирьох водосховищ, системи каналів відвело поверхневі води, зменшило затоплення і підтоплення території. За відсутності урахування природоохоронних вимог, глибокого всебічного аналізу при реалізації проектних рішень різко скоротилась чисельність фауни, включаючи риб виду умбра звичайна (Umbra krameri Walbaum, 1792). 
Комплексна техногенна експлуатація водойм породжує перебудову біосистем. Заготівля та вивезення 3 річок гравію, піску, каміння, намулу знищує місця природного існування риб, нерідко лососевих і зникаючих. Втрачаємо іхтіофауну через дію водозабірних споруд міських насосних станцій, зрошуваних систем, Теребле-Рікської та інших гідроелектростанцій (ГЕС). Реакція, особливо молоді риб, на потоки води, яку забирають користувачі, гостро специфічна i при поодинокому перебуванні, й при масових скупченнях. Зміна гідравлічних параметрів, турбулентість спонукає iї до вияву природних реакцій, включення механізмів міграційної поведінки і запливання у водозабірні споруди. Сюди, за підрахунками спеціалістів потрапляють тисячі особин риб та інших гідробіонтів, а відтак гинуть, С. Алімов, 2008 (Alymov, 2010).

Продовжується збільшення викидів шкідливих речовин в атмосферне повітря стаціонарними і пересувними джерелами. Відчутного удару рослинності, грунтам, водотоками, а через них усьому живому та неживому в природі завдають викиди місцевих промислових підприємств і країн Центральної Свропи сірчистого ангідриду - джерела кислотного дощу ( $\mathrm{pH}<5,6$ опади вважаються кислими, Смітт, 1992), забрудненого важкими металами, сіркою снігу. Відхилення нейтральних значень рН води в кислий бік у лососевих утруднює процес поглинання кисню 3 середовища, в зябрах проходить абсорбція розчиненого алюмінію, порушується дихальна та іонорегуляторна функція зябер. Ослаблення респірації може спричинити їх загибель (Т. Струбіцька й ін., 1991).

Основні постачальники токсинів: транскордонні переноси забруднюючих речовин повітряними течіями, автомобільний транспорт, спалювання минулорічної рослинності, органічних відходів, побутового сміття. Вимиваючи забруднюючі речовини з атмосфери, опади самі собою починають відігравати роль фактора екологічного ризику. При конденсуванні атмосферної вологи на частках $\mathrm{NO}, \mathrm{NO}_{2}, \mathrm{SO}_{2}$ утворюються розчини азотної, азотистої та сірчаної кислот. На території Карпат щорічно розсіюється з атмосферними опадами 0,62 млн т розчинених мінеральних речовин, тобто в розрахунку на 1 км $^{2}$ 29,9 т (Adamenko et al., 2005). За рік промислові підприємства і організації області, спалюючи органічне паливо, викидають у повітря 31 тис. т шкідливих речовин, продукують 75 типів газоподібних сполук. Автомобільний транспорт - 55,6 тис. т, 3 них 40,9 тис. т оксид вуглецю. Середньорічний рівень забруднення атмосферного повітря міста Ужгорода в 2011 році становив:

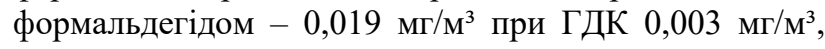
що в 6,3 разу перевищує ГДК, діоксином азоту 0,053 мг/м, ${ }^{3}$ перевищення - 1,33 ГДК (Homonai et al., 2013). Внаслідок цього висохло майже 1500 га дубових лісів.

Ліквідація 1280 кілометрів вузькоколійних залізничних доріг та перехід з 1971 року на транспортування деревини автотранспортом (близько 5 тис. одиниць), трелювання лісу гусеничними тракторами залишає після себе високий рівень руйнування грунту, всього біогеоценотичного комплексу, насичене кан- церогенними і важкими металами середовище, забруднення води паливно-мастильними матеріалами.

Експлуатація 1700 км газо-нафто, продуктопроводів, які в 10 тис. місцях перетинають річки, що відпрацювали свій амортизаційний термін, супроводжується частими аварійними надходженнями складових природного газу і нафти у навколишнє середовище. Аналогічні наслідки несанкціонованих ,врізок.” За інформацією лінійної служби Ужгородського міжрайонного управління водного господарства, останній інцидент відбувся 17 вересня 2015 року біля с. Ворочаво Перечинського району, під час якого забруднено 300 м $^{2}$ річки Уж дизельним паливом - 0,53мг/л, що у 2 рази перевищувало допустимі норми. Концентрації нафтопродуктів у пробах грунту с. Великий Бичків (котельня колишнього лісохімкомбінату) Рахівського району перевищують фонові показники від 3 до 50 разів. Забруднюючих речовин поверхневих вод з хімічного споживання кисню до 3 разів, з умісту фенолів - 3000 разів (потік б/н перед впаданням в річку Шопурка притоку Тиси). Безпосередньо в річці Шопурці вміст фенолів перевищує ГДК в 30 разів (Ekolohichnyi pasport Zakarpatskoi oblasti..., 2015). Постійний відтік відбувається 3 відстійників компресорних станцій магістралей. Феноли - похідні нафтопродуктів - в Ужгородському районі виявлено у грунтових водах на глибині до 200 м. При потраплянні нафтопродуктів у воду через декілька діб в результаті хімічного і біохімічного розпаду утворюються токсичні окислені вуглеводи (концентрація 0,5 мг/л - гине риба, 1,2 мг/л планктон та бентос).

Гірська територія області займає майже $80 \%$ iii площі. Із 1275,3 тис. га земель $90 \%$ розміщені на схилах крутизною понад 5 градусів. Всього сільськогосподарських угідь 452 тис. га, в тому числі ріллі 199,9 тис. га. Неврахування в системі землекористування ступінчастості та ярусності рельєфу, великої розчленованості гірських схилів, густої мережі річок, надмірне захоплення та безсистемне застосування мінеральних добрив, гербіцидів, пестицидів зумовило ситуацію підвищеної небезпеки. 3 мінеральними добривами у грунт, потім у воду і живі організми потрапляють токсичні сполуки (фтор, хлор), важкі метали,

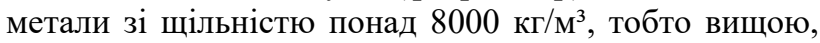
ніж щільність заліза, що містяться в них як баластні елементи. Вміст їх у мінеральних і органічних добривах та меліорантах за Н.А.Черних, наведено в табл. 5.

\section{Таблиця 5}

Кількість важких металів у засобах хімізації, мг/кг

\begin{tabular}{lccccc}
\hline \multirow{1}{*}{ Засоби хімізації } & \multicolumn{5}{c}{ Важкі метали } \\
\cline { 2 - 6 } & $\mathrm{Cd}$ & $\mathrm{Pb}$ & $\mathrm{Zn}$ & $\mathrm{Cu}$ & $\mathrm{Ni}$ \\
\hline Подвійний суперфосфат & 3,7 & 39 & 48 & 14 & 29 \\
Хлористий калій & 3,9 & 14 & 11 & 3,6 & 21 \\
Аміачна селітра & 0,2 & 18 & 7,1 & 1,0 & 8 \\
Вапнякова мука & 0,18 & 28 & 22 & 6,3 & 24 \\
Гній & 0,2 & 4 & 112 & 22 & 7,2 \\
\hline
\end{tabular}

Свинець належить до важких металів першого класу небезпеки. Цинк і мідь - елемент другого класу, нікель - суперекотоксикант. Систематичне внесення 
мінеральних добрив на темно-сірих опідзолених грунтах сприяло збільшенню вмісту рухомого цинку. При надходженні важких металів в грунт вони нагромаджуються і довгий час залишаються у середовищі або, мігруючи, стають джерелом повторного забруднення.

Дані таблиці вказують на найвищий вміст цих токсикантів у подвійному суперфосфаті, цинку у гною, найменша кількість - в азотних добривах. Доза застосування мінеральних добрив при вирощуванні технічних культур, що набрало стрімкого поширення, складає $\mathrm{N}-180, \mathrm{P}-150, \mathrm{~K}-200$ кг/га, гною - 60 т/га. За рік у грунт надійде важких металів кг/га: $\mathrm{Cd}-0,12$, $\mathrm{Pb}-0,79, \mathrm{Zn}-7,20, \mathrm{Cu}-1,33, \mathrm{Ni}-0,81$. Отже, застосування засобів хімізації для вирощування сільськогосподарських культур за інтенсивними технологіями призводить до забруднення шкідливими речовинами агроекосистеми. Крім того грунти гірських районів характеризуються підвищеним вмістом рухомих форм свинцю, який в окремих випадках перевищує ГДК, кадмію - 0,7 мг/кг.

У літературі достатньо широко висвітлені особливості, характер та механізм дії зазначених вище речовин переважно на рівні летальних доз. Нагромаджена інформація недостатня для прогнозування наслідків комбінованої дії на рівні порогових та підпорогових доз, під впливом яких перебувають риби у зонах локального техногенного навантаження. Таке на досліджувані водні об’єкти чинить сусідня Румунія аварійними скиданнями ціанідів та важких металів заводом Байя-Борша, розташованим за 30 км від кордону. На щастя, аварії трапляються не часто. Румунськими службами 30 січня 2000 року з води виловлено понад 1200 т мертвої риби. Останній прорив дамби відстійника "Колбу" відбувся у липні 2009 року. Разом $з$ водою ціаніди і важкі метали злили у річку Валя Вішеулуй, ліву притоку Тиси (с. Ділове, Рахівський рн). На відміну від органічних сполук, важкі метали не піддаються деструкції, а постійно присутні у водних екосистемах. Акумулюючись у фітопланктоні, зоопланктоні, зообентосі, детриті та вищій водній рослинності вони за трофічними ланцюгами та безпосередньо $з$ води надходять до організму риб, суттєво впливаючи на біоенергетичні процеси, ритм розмноження, функціонування репродуктивної системи. Тому цю обставину варто враховувати.

Маючи кумулятивні властивості пестициди циркулюють і накопичуються в організмах практично всіх гідробіонтів, але особливо високі концентрації пестицидів та їхніх метаболітів виявляються у риб, що впливає на експресію геному, а отже і на синтез білків, які своєю чергою регулюють метаболізм та фізіологічні функції риб. Порушують структуру зябер, знижують тривалість згортання та в'язкість крові, кількість еритроцитів, змінюють біохімічні показники крові, що може позначитися на фізіологічному і популяційному рівні. Пік використання пестицидів у кількості 2180,5 т припадає на 1986 рік. Оброблена площа досягала 183,2 тис. га. Навантаження на гектар орної землі становило 11,9 кг/га. Внесені в агробіоценози хімічні засоби, понад 20 видів, включалися в численні цикли екологічних зв'язків, що охоплювали не тільки грунт, біоту, а й грунтові та поверхневі води, рослинність, атмосферу, тварин, всю агроекосистему і людинy (Braginskij, 1972; Manivchuk, 2003; Zhidenko \& Kovalenko, 2006).

Не менша шкода від консервантів, стабілізаторів, які потрапляють в організм сільськогосподарських тварин 3 комбікормами, виводячись, мігрують, трансформуються у довкілля.

Дуже небезпечні синтетичні миючі засоби (руйнують мембрани клітин риб), пластикова тара, комунальні стоки і побутові відходи. Речовини, що виробляються фармакологічними компаніями, їхні прекурсори та метаболіти. Значна кількість ліків потрапляє у каналізацію, а вже звідти у річки. Діючі речовини їх навіть у наднизьких концентраціях, від мкг/дм ${ }^{3}$ до нг/дм ${ }^{3}$, характеризуються гострою і хронічною токсичністю для гідробіонтів, формують генетичну резистентність до фармакологічних препаратів у мікроорганізмів (Korzh et al., 2016). В принципі, водні організми постійно піддаються комплексній дії антибіотиків, анальгетиків, антикольвуйсивних засобів, транквілізаторів. За літературними даними, навіть після обробки на очисних спорудах у стічних водах виявлено 170 різних лікарських препаратів. Натомість 3 обстежених 21 виробничого управління житловокомунальних господарств 18 включено до переліку основних забруднювачів. За повідомленнями, усього скинуто зворотних вод у поверхневі водойми краю протягом року 48,33 млн м², в тому числі неочищених і недостатньо очищених 12,06 млн м³. Вивозиться на місця розміщення 500-600 тис. м $^{3}$ побутового сміття, якого щорічно накопичується в розрахунку на одного мешканця 9,2 т, що в 1,5 разу вище, ніж у країнах СС (Borodenko et al., 1983; Alymov, 2010; Hromyko \& Pashkov, 2015). Нагромаджується 50 тис. ртутних ламп і ліхтарів.

Проблема відходів має високу гостроту через повільність їхнього розкладання. Папір руйнується протягом 2-10 років, консервні банки майже за 100 років, поліетиленові матеріали - за 200 років, пластмаса - за 500 років. Скло для повного розкладу потребує 1000 років. Перераховане й забруднення природних вод відходами промислового і сільськогосподарського виробництва, каналізаційними стоками, побутовим сміттям спричинило в багатьох водоймах різке погіршення гідрологічного та гідрохімічного режимів, кормової бази, біокумуляцію, біомагніфікацію полютантів у трофічних ланцюгах, серйозні порушення розвитку і загибель риб, особливо в ембріональний період життя, необоротні зміни на клітинному рівні.

На нашу думку, причиною того, що вже багато років чисельність струмкової форелі, харіуса європейського, лосося дунайського, стерляді прісноводної та інших цінних видів риб перебуває на такому низькому рівні, $є$ рівень життя місцевого населення. Дані державної статистики про його чисельність наведено в таблиці 6. 
Таблиця 6

Населення Закарпатської області та кількість населених пунктів, на початок року

\begin{tabular}{|c|c|c|c|c|}
\hline \multirow{2}{*}{ Показники } & \multirow{2}{*}{$\begin{array}{c}\text { Одиниця } \\
\text { виміру }\end{array}$} & \multicolumn{2}{|c|}{ Роки } & \multirow{2}{*}{$\begin{array}{c}2018 \text { y \% } \\
\text { до } 1921\end{array}$} \\
\hline & & 1921 & 2018 & \\
\hline Чисельність населення & тис. осіб & 604,7 & 1259,6 & 208,3 \\
\hline Населені пункти & кількість & 478 & 609 & 127,4 \\
\hline Площа & тис. км² & 12,6 & 12,8 & 101,6 \\
\hline Припадає осіб на 1 км² & кількість & 47,9 & 98,4 & 205,4 \\
\hline
\end{tabular}

Щодо останнього, то тут треба відмітити його подвоєння за останні сто років та значну щільність і концентрацію людських поселень вздовж річок. Висока демографічна щільність поширюється і на гірську місцевість. Ситуація ускладнюється й тим, що 3 ростом населення збільшується кількість неорганізованих рибалок, які займаються споживацьким рибальством. Дослідники Кузьменко, Спасивий вказують, що тільки 30\% рибалок вважають риболовлю засобом відпочинку, а 70\% засобом задоволення особистих матеріальних потреб.

Близько 50\% ловлять рибу для споживання, 20\% на продаж. В їхніх уловах частка цінних промислових видів риб сягає 57,7\%, до того ж 95\% складають нестатевозрілі особини (Kuzmenko \& Spesyvyi, 2008). Браконьєри використовуючи заборонені риболовецькі засоби винищують іхтіофауну. Спонукає людей на такі дії низький загальний рівень життя та існуюча система охорони, яка $€$ неефективною. Боротися 3 порушниками рибної ловлі добре було б, використовуючи групові методи патрулювання, здійснюючи регулярні рейди, які забезпечать пошук, швидке затримання їх, збір необхідних доказів. Важливу роль у викоріненні таких явищ може відіграти підвищений рівень світогляду місцевих громад, екологізація суспільно-економічних відносин, подолання бідності, утвердження принципу: громада - реальний господар довкілля. Економічний аспект користування рибними ресурсами не повинен вступати в протиріччя із біорізноманіттям. Має проводитися робота, спрямована на зупинку процесів деградації суспільства і природи, збереження цінних, рідкісних та зникаючих видів риб.

Таким чином, можна константувати, що кожен зі згаданих факторів безпосередньо чи опосередковано призводить до зменшення запасів іхтіофауни, впливає на просторове розміщення популяцій і окремих особин виду, включаючи лососеві. Порушує природну, територіальну й ієрархічну структуру популяцій (динаміку чисельності особин, співвідношення статей, віковий склад, щільність заселення). Негативно позначається на життєздатності, самовідтворюваності, можливості обміну генетичною інформацією. Може викликати ланцюгову реакцію в біоценозі, спричинити коливання чисельності популяцій інших видів, цілковитої їх загибелі. В природі кожний вид організмів відіграє певну і тільки йому властиву роль. Зникнення одного виду автоматично тягне за собою зникнення багатьох інших, об'єднаних спільним трофічним ланцюгом. Це не відповідає концепції стійкого, збалансованого розвитку Закарпаття, міжнародним програмам і стратегіям збереження, охорони та відродження екосистем Свропи. Тому треба дбайливо обе- рігати генетичне, внутрішньовидове і видове різноманіття риб басейну річки Тиси шляхом контролю кваліфікованими спеціалістами за окремими популяціями, визначення можливих змін, об'єктивно оцінювати їхній стан 3 метою негайного вживання, в разі потреби, необхідних заходів. Поліпшити його можна шляхом вселення цінних риб або створення умов для швидкого формування самовідтворення популяцій.

Однак реалії засвідчують протилежне. На гірських річках в Закарпатті заплановано будівництво 360 малих ГЕС, внаслідок чого, наголошують фахівці, активізуються зсуви, селі та ерозійні процеси, зміниться гідрологічний режим територій, буде порушено прирічкові ліси, погіршиться якість води в річках і загалом у регіоні, зникне більшість водних організмів, включаючи червонокнижні.

\section{Висновки}

Динаміка природного поновлення іхтіофауни залежить від багатьох факторів: кормової бази, чисельності плідників, епізоотичного стану водойм, антропогенного тиску і т.д.

Риби басейну річки Тиси, включаючи лососеві, вже не у повній мірі витримують екологічний тиск зменшують ріст і розвиток, чисельність, змінюють віковий та видовий склад. Крім того, збідненим популяціям притаманна підвищена чутливість до стресів.

Враховуючи те, що Тиса охоплює території України, Румунії, Угорщини, Словаччини та Сербії, впадаючи в Дунай, складає річкову систему Свропи, визначилась важливість формування нової моделі співробітництва держав щодо збереження екорегіону, моніторингу екологічного стану води, епізоотичної ситуації, міграційних процесів, вивчення загроз для біогеоценозів та усунення їх, використовуючи доступні методики.

Попередні результати вказують на необхідність та перспективу подальших досліджень загроз лососевим і зникаючим рибам, які разом із матеріалами інвентаризації значно доповнять відомості про іхтіофауну басейну річки Тиси і фактори загроз для неї.

Є причини вважати, що повідомлені в нашій роботі результати досліджень приведуть до ліпшого розуміння стану, який склався із популяціями струмкової форелі, харіуса європейського, лосося дунайського, аборигенних видів риб і гідроекосистемою української ділянки річки Тиси та приток, і допоможуть передбачити наслідки впливу загроз в майбутньому. Візуалізація загроз дозволить прогнозувати можливість виродження або стабілізацію і розвиток популяцій на іншому рівні системної організації. 


\section{References}

Dovbenko, V.I. (2007). Umovy formuvannia ekolohoekonomichnoho mekhanizmu rehionalnoho rozvytku. Mat. mizhnar. naukovo-praktychnoi konf. "Ekoturyzm i stalyi rozvytok u Karpatakh". Rakhiv, 95-100 (in Ukrainian).

Mruk, A.I., Ustych, V.I., \& Buzevych, I.Iu. (2011). Vidtvorennia ta popovnennia pryrodnoho arealu strumkovoiu forelliu na prykladi r. Irshava Rybohospodarska nauka Ukrainy, 3, 40-46. http://nbuv.gov.ua/UJRN/rnu_2011_3_8 (in Ukrainian).

Pop, S.S. (2002). Pryrodni resursy Zakarpattia. Uzhhorod: TOV "Spektral" (in Ukrainian).

Akimov, I.A. (2009). Chervona knyha Ukrainy (Tvarynnyi svit). K.: Hlobalkonsaltynh (in Ukrainian).

Meteleshko, Iu.O., \& Potish, L.A. (2011). Chervona knyha Ukrainskykh Karpat (Tvarynnyi svit). Uzhhorod, Karpaty (in Ukrainian).

Koliushev, I.I. (1949). Korotkyi vyznachnyk ryb Zakarpatskoi oblasti URSR. Uzhhorod (in Ukrainian).

Mruk, A.I., Velykopolskyi, I.I., \& Ustych, V.I. (2012). Yevropeiskyi kharius baseinu r. Tereblia ta aspekty yoho shtuchnoho vidtvorennia. Rybohospodarska nauka Ukrainy, 1, 53-61. http://irbis-nbuv.gov.ua/cgibin/opac/search.exe?I21DBN=LINK\&P21DBN=UJR $\mathrm{N} \& Z 21 \mathrm{ID}=\& \mathrm{~S} 21 \mathrm{REF}=10 \& \mathrm{~S} 21 \mathrm{CNR}=20 \& \mathrm{~S} 21 \mathrm{STN}=1$ $\& S 21 \mathrm{FMT}=\mathrm{ASP}$ meta\&C21COM=S\&2_S21P03=FI $\mathrm{LA}=\& 2$ S21STR=rnu 2012111 (in Ukrainian).

Sherman, I.M., Tymchenko, Yu.V., \& Shevchenko, P.H. (2009). Zahalna ikhtiolohiia: Pidruchnyk. K.: Ahrarna osvita (in Ukrainian).

Hrytsyniak, I.I. i in. (2008). Fermerske rybnytstvo. K.: Herb (in Ukrainian).

Kosovets, O.O., \& Samoilenko, N.A. (2005). Katastrofichni hidrolohichni yavyshcha na zlami stolit v Ukrainskykh Karpatakh. Materialy mizhnarodnoi naukovo-praktychnoi konferentsii. Rakhiv, 198-205 (in Ukrainian).

Proniuk, D.A. (2011). Istoriia vodnoho hospodarstva Zakarpatskoi oblasti. Uzhhorod: IVA (in Ukrainian).
Kyselov, M.M., \& Kanak, F.M. (2000). Natsionalne buttia sered ekolohichnykh realii. K. (in Ukrainian).

Adamenko, Ya. i in. (2005). Kyslotni doshchi nad Hoverloiu? Zeleni Karpaty, 1, 2, 66-68 (in Ukrainian).

Homonai, V.I., Bohosta, A.S. i in. (2013). Otsinka zabrudnennia atmosfernoho povitria Uzhhoroda. Ekolohichnyi zhurnal, 6, 16-17 (in Ukrainian).

Ekolohichnyi pasport Zakarpatskoi oblasti za 2014 rik (2015), Uzhhorod (in Ukrainian).

Manivchuk, Yu.V. (2003). Ekolohichno efektyvna systema biomelioratsii hirskykh hruntiv Karpat za dopomohoiu biokompostiv. Naukovyi visnyk Uzhhorodskoho universytetu. Ser. Biolohiia, 13, 9295 (in Ukrainian).

Zhidenko, A.O., \& Kovalenko, E.M. (2006). Vlijanie raundapa na dinamiku gistologicheskih pokazatelej $\mathrm{v}$ organah karpa. Gidrobiologicheskij zhurnal, 42(6), 104-111 (in Russian).

Braginskij, L.P. (1972). Pesticidy i zhizn' vodoemov. Kiev: Naukova dumka (in Russian).

Korzh, E.A. i in. (2016). Vlijanie harakteristik aktivnyh uglej na jeffektivnost' izvlechenija iz vody farmacevpticheskih preparatov razlichnoj himicheskoj prirody. Himija i tehnologija vody, 2, 150-160 (in Russian).

Borodenko, I.I., Lozanovskaja, I.N. i dr. (1983). Kompleksnoe ispol'zovanie i ohrana vodnih resursov. M.: Kolos (in Russian).

Hromyko, M.H., \& Pashkov, A.P. (2015). Svitovi ekoloho - ekonomichni priorytety u vyrishenni problem vidkho-div. Bezpeka zhyttiediialnosti, 19-22 (in Ukrainian).

Alymov, S.I. (2010). Ekolohichni zminy vodnykh ekosystem pry antropohennykh navantazhenniakh: naukove vydannia. Kharkiv: Oberih (in Ukrainian).

Kuzmenko, Yu.H., \& Spesyvyi, T.V. (2008). Suchasnyi stan ta deiaki aspekty rehuliuvannia amatorskoho rybalstva yak istotnoho chynnyka antropohennoho vplyvu na ikhtiofaunu vnutrishnikh vodoim Ukrainy. Rybohospodarska nauka Ukrainy, 3, 23-29 (in Ukrainian). 